\title{
Biological and Contaminant Investigations, Upper Colorado River Basin- What's Been Done and How Can the Information Be Used?
}

\section{-Jeffrey R. Deacon}

As part of the U.S. Geological Survey's National Water-Quality Assessment (NAWQA) program, an inventory of biological and contaminant investigations was conducted for the Upper Colorado River Basin (UCOL) study unit. Investigations conducted in the basin since 1938 were identified and categorized. The resulting information can be used to design biological sampling strategies to fill gaps in the biological and contaminant data and to effectively address water-quality issues in the UCOL study unit.

\section{INTRODUCTION}

The NAWQA program is designed to integrate physical, chemical, and biological components to assess water quality in 60 river basins nationwide. The biological component of this program focuses on: (1) Biological communities (algae, macroinvertebrates, and fish); (2) stream habitat characterizations; and (3) trace-element and organic contaminants in aquatic tissues and bed sediment (Gurtz, 1994). Existing biological and contaminant information was inventoried as the first step for implementation of the biological component of the NAWQA program for the UCOL study unit. The inventory of the historical data indicated the types of biological information available for the basin, the gaps in this information, and the implications for water-quality issues. Hydrology, climate, geology, topography, and land use vary substantially within the UCOL study unit and directly affect stream biology in the study unit. Therefore, these natural and human factors (Apodaca and others, 1996) were important in the information inventory.

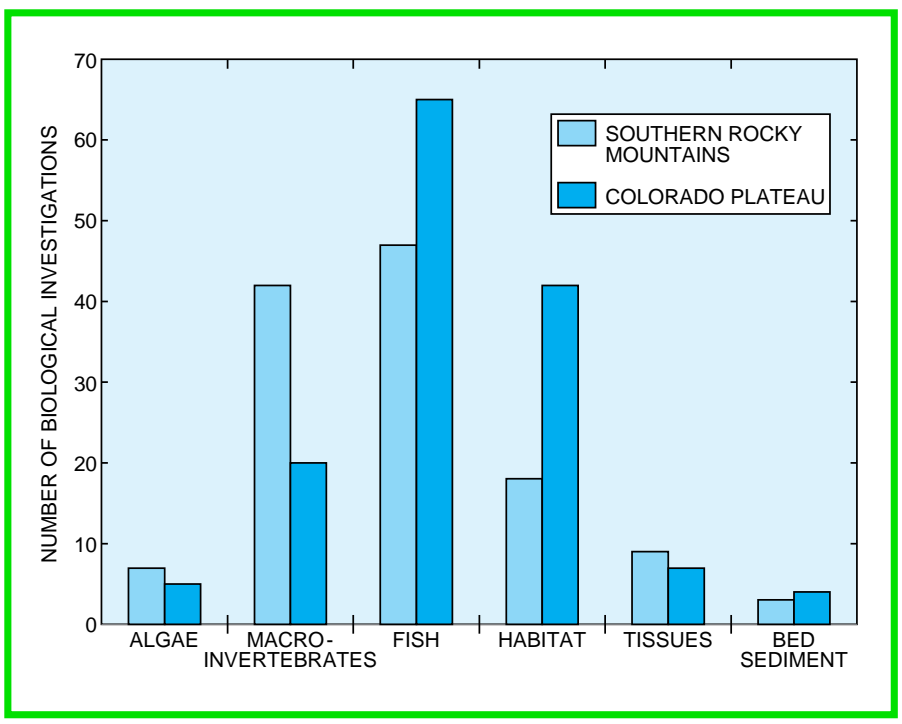

Number and type of biological investigations in comparison to the physiographic provinces.

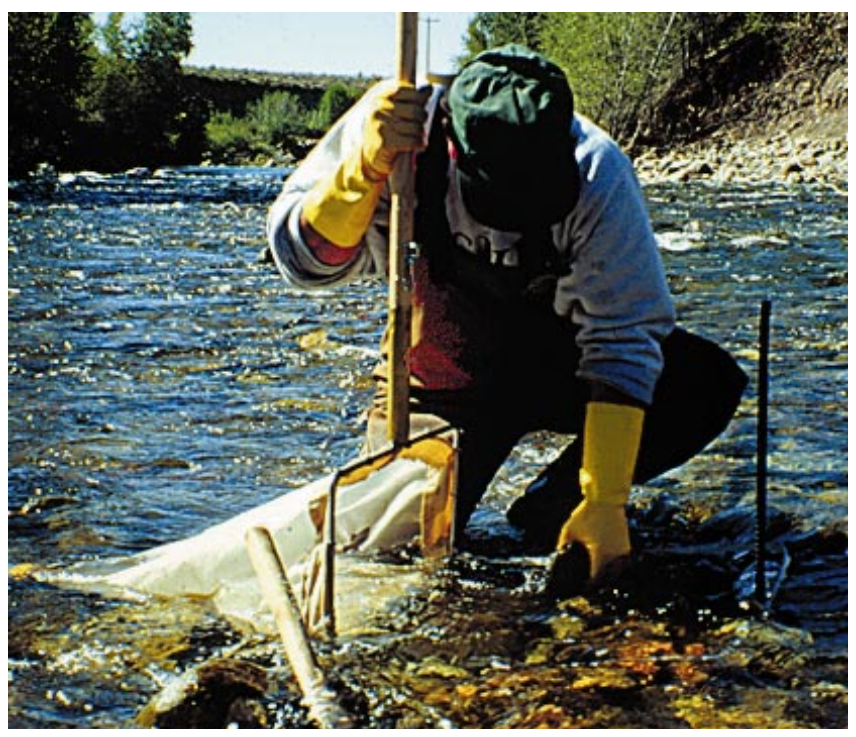

\section{BIOLOGICAL AND CONTAMINANT INVESTIGATIONS}

Four categories of biological investigations (algal, macroinvertebrate, and fish communities and habitat characterization), and two categories of contaminant investigations (contaminants in organism tissue and contaminants in bed sediment) were included in the biological inventory. One-hundred-twenty-six investigations were compiled and categorized. The studies were categorized by their locations in two physiographic provinces, the Southern Rocky Mountains and the Colorado Plateau, and by the predominant land use in the area of investigation. A more detailed description of the historical, biological, and contaminant investigations; information on biological communities; gaps in biological information; and land-use effects on biological communities in the study unit is in Deacon and Stephens (1996).

Studies on macroinvertebrate and fish communities and habitat characterization were the most common types of biological investigations conducted in the basin. Few studies have been conducted on algal communities and contaminants in organism tissue and in bed sediment in the UCOL.

The physiographic provinces in the study unit differ greatly in altitude, climate, vegetation, and geologic formations. The diverse habitats provide for a variety of aquatic biological communities. The Southern Rocky Mountains physiographic province 
consists of streams with steep gradients; cobble and boulder substrate; and cool, clear, forested headwaters traversing crystalline bedrock at high altitudes that have extended periods of ice and snow cover. Lower gradient streams of the Colorado Plateau physiographic province consist of sand and silt substrate; sparse vegetation; and warmer, more saline water that flows through sedimentary rocks. Distinct biological communities are associated with the two physiographic provinces principally because algae, macroinvertebrates, and fish of the UCOL vary with altitude and physical habitat. In general, the predominant biological communities in the Southern Rocky Mountains province consist of green algae and diatoms; caddisflies, mayflies, and stoneflies; and cold-water fish species, including trout. The predominant biological communities in the Colorado Plateau province consist of blue-green, goldenbrown, and green algal species; aquatic worms, dobsonflies, and crayfish; and warm-water fish species, including carp, catfish, and suckers.

\section{LAND-USE EFFECTS}

Mining activities have severely altered aquatic life and habitat in many of the headwater reaches of the Colorado River and its tributaries (Colorado Water Quality Control Division, 1989). As tributaries with different water chemistry converge and mix, precipitation of metals can occur. This precipitation can directly affect certain biological communities and habitat by coating the substrate with toxic constituents. The coating decreases habitat availability and provides a mechanism for contamination.

Urbanization in the UCOL study unit has become increasingly important in its effects on water quality and its associated effects on biological communities. Development and construction activities can increase sedimentation, which adversely affects water quality and, therefore, affects algae, macroinvertebrate, and fish life by decreasing light, decreasing habitat availability, and having the potential of increasing contaminant loads in streams.

Agricultural activities also affect water quality in the study unit. Nutrients derived from fertilizers can indirectly cause detrimental effects on aquatic fauna by overstimulating the growth of various algal species. Pesticides commonly are used in agricultural areas in the study unit and can cause damaging effects on the biota because of acute or chronic toxic exposure. Studies conducted on the water quality of irrigation return flows in the study unit have indicated adverse effects on biota from pesticides and selenium, a naturally occurring element in the soil.

\section{SAMPLING DESIGN}

The biological component of the NAWQA program consists of characterizing algal, macroinvertebrate, and fish communities and habitat at each surface-water sampling site and analyzing fish tissue and bed sediment for trace-element and organic contaminants. The resulting information can be integrated with physical and waterchemistry data to provide multiple lines of evidence for the assessment of water quality in the UCOL study unit. A more detailed description of surface-water sampling sites in the study unit is in Spahr and others (1996).

The sampling design for the biological component in the UCOL study unit is enhanced by the inventory of existing biological and contaminant information. This information also can be useful in the selection of sampling sites for future studies and for avoidance of duplicative studies. Identified gaps in the biological data can be addressed to meet national needs of the NAWQA program and local needs in the study unit. The biological inventory can be used to select biological sampling sites; design sampling strategies; and integrate physical, chemical, and biological information for the UCOL study unit.

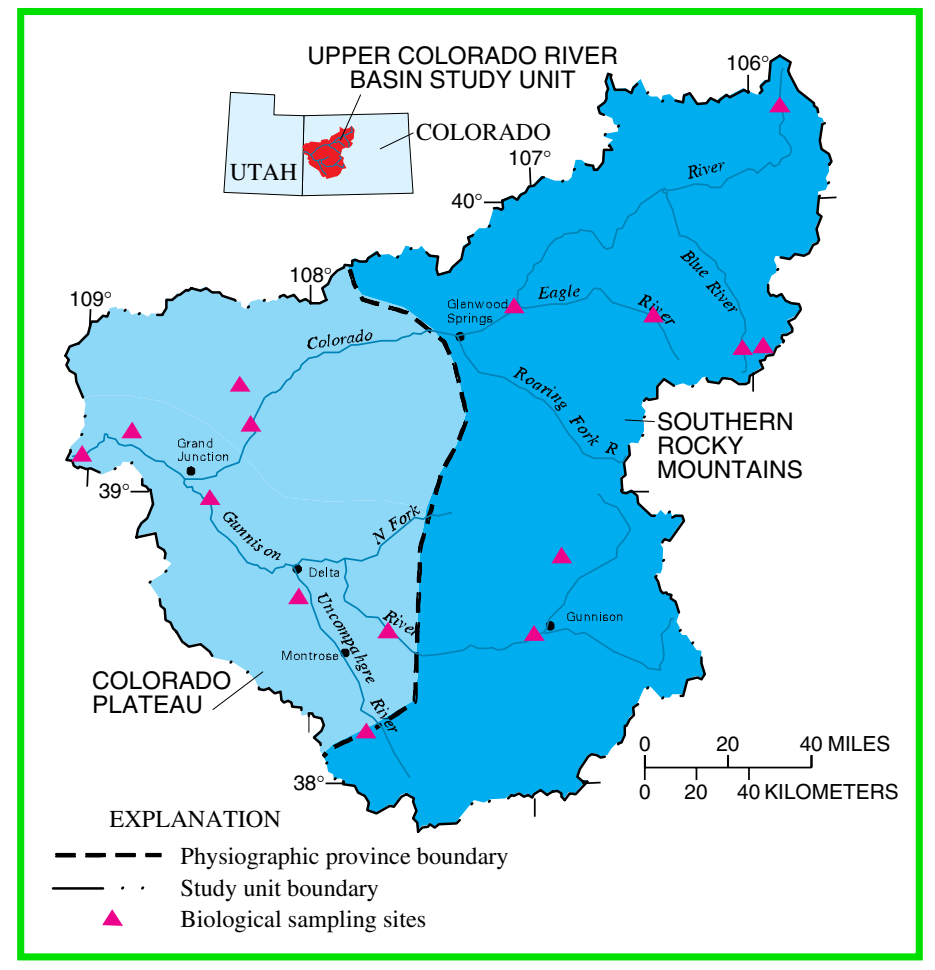

Location of Upper Colorado River Basin study unit, physiographic provinces, and biological sampling sites.

\section{REFERENCES CITED}

Apodaca, L.E., Driver, N.E., Stephens, V.C., and Spahr, N.E., 1996, Environmental setting and implications on water quality, Upper Colorado River Basin, Colorado and Utah: U.S. Geological Survey Water-Resources Investigations Report 954263, 33 p.

Colorado Water Quality Control Division, 1989, Colorado nonpoint assessment report-1989 addendum: Denver, Colorado Department of Health, $189 \mathrm{p}$.

Deacon, J.R., and Stephens, V.C., 1996, Summary of biological and contaminant investigations related to stream water quality and environmental setting in the Upper Colorado River Basin, 1938-95: U.S. Geological Survey Water-Resources Investigations Report 96-4172, 37 p.

Gurtz, M.E., 1994, Design of biological components of the National Water-Quality Assessment (NAWQA) program, chap. 15 of Loeb, S.L., and Spacie, Anne, eds., Biological monitoring of aquatic systems: Boca Raton, Fla., Lewis Publishers, p. 323-354.

Spahr, N.E., Driver, N.E., and Stephens, V.C., 1996, The Upper Colorado River National Water-Quality Assessment program surface-water-monitoring network: U.S. Geological Survey Fact Sheet 191-96, 4 p.

Information on technical reports and hydrologic data related to the NAWQA program can be obtained from:

Upper Colorado River Basin NAWQA Manager

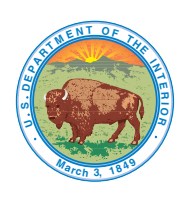
U.S. Geological Survey Denver Federal Center Mail Stop 415, Box 25046 Lakewood, CO 80225 (303) 236-2101 ext. 224 email: nedriver@usgs.gov 